\title{
Isolasi dan karakterisasi biokimia bakteri pembusuk buah cabai rawit
}

\section{Isolation and biochemistry characterization spoilage bacteria in cayenne pepper fruit}

\author{
Yoga Aji Handoko ${ }^{1)^{*}}$, Yulius Adi Kristiawan ${ }^{1)}$, Yohanes Hendro Agus ${ }^{1)}$ \\ ${ }^{1}$ Program Studi Agroteknologi, Fakultas Pertanian dan Bisnis, Universitas Kristen Satya Wacana \\ Jalan Diponegoro No. 52-60, Salatiga, Jawa Tengah, Indonesia \\ *e-mail: yoga.handoko@uksw.edu
}

Informasi Artikel:

Dikirim: 15/02/2020; ditinjau: 16/02/2020; disetujui: 20/03/2020

\begin{abstract}
Cayenne pepper (Capsicum frutescens L.) is a species of chili that is usually consumed daily and used by the food industry. Although cayenne pepper has important roles, it is often found rotting before it is reached by consumers. Postharvest handling that did not apply good handling practices can causes decomposition of cayenne peppers. This decayed can be caused by the activity of microorganisms, such as bacteria. This study aims to isolate and examine the biochemical properties of spoilage bacteria in cayenne pepper. The stages of the experiment involved: isolation and purification of the bacteria, observation of cell morphology and colonies, and biochemical examination. The results showed that bacterial isolates in cayenne pepper had rod-shaped cell characteristics, shiny colony surfaces, and jagged colony edges. Biochemical characteristics show that these bacteria have enzyme catalase activity, phosphatase enzyme activity, are able to produce carotenoid and lecithinase. However, these bacteria can not hydrolyze starch and pectin. These biochemistry characteristics were not identic with Xanthomonas campestris. Based on the assessment of lactose fermentation, indole, methyl red, and Voges-proskaeur, these bacteria could not be identified as Erwinia carotovora.
\end{abstract}

Keywords: biochemistry, cayenne pepper, characterization, isolation, spoilage bacteria

\begin{abstract}
ABSTRAK
Cabai rawit (Capsicum frutescens L.) merupakan spesies cabai yang berperan di bidang industri makanan maupun konsumsi harian masyarakat. Meskipun cabai rawit mempunyai peranan yang penting, seringkali cabai rawit ditemui telah membusuk sebelum sampai di tangan konsumen. Penanganan pascapanen yang tidak menerapkan standar penanganan yang baik dapat menyebabkan terjadinya pembusukan pada buah cabai rawit. Pembusukan ini dapat disebabkan oleh aktivitas mikroorganisme, seperti bakteri. Penelitian ini bertujuan untuk mengisolasi dan menguji sifat biokimia bakteri pembusuk dalam buah cabai rawit. Tahapan penelitian yang dilakukan meliputi: isolasi dan purifikasi bakteri, pengamatan morfologi sel dan koloni, serta uji biokimia. Hasil penelitian menunjukkan bahwa isolat bakteri pembusuk dalam cabai rawit mempunyai ciri sel yang berbentuk batang, permukaan koloni mengkilap, dan tepi koloni bergerigi. Karakteristik biokimia menunjukkan bahwa bakteri tersebut mempunyai aktivitas enzim katalase, aktivitas enzim fosfatase, mampu memproduksi karotenoid, dan mampu memproduksi lechitinase. Namun demikian, bakteri tersebut tidak dapat menghidrolisis pati dan pektin. Karakteristik biokimia tersebut tidak identik dengan bakteri Xanthomonas campestris. Pengujian fermentasi laktosa, indol, methyl red, dan Voges-
\end{abstract}


Proskaeur juga menunjukkan bahwa bakteri pembusuk buah cabai rawit tersebut bukan spesies bakteri Erwinia carotovora.

Kata kunci: bakteri pembusuk, biokimia, cabai rawit, isolasi, karakterisasi

\section{PENDAHULUHAN}

Capsicum frutescens L. atau yang dikenal cabai rawit merupakan salah satu jenis sayuran yang sangat penting di Indonesia (FAO, 2014). Buah cabai memiliki berbagai nilai nutrisi, diantaranya, berbagai macam mineral serta vitamin dengan kandungan antioksidan yang tinggi, seperti: vitamin $\mathrm{C}$, vitamin $\mathrm{E}$, vitamin $\mathrm{K}$, fitosterol, beta-karoten, dan beta-kriptosantin (Suyanti, 2009). Dari sisi nilai ekonomisnya dan konsumsinya, cabai mempunyai peluang pasar besar dan luas dengan rata-rata konsumsi cabai 5 kg/kapita/tahun 2013 dan $90 \%$ cabai rawit dikonsumsi dalam bentuk segar (Prajnanta, 2007; Dermawan dan Harpenas, 2010; Badan Pusat Statistik, 2015).

Budidaya cabai, khususnya cabai rawit memang menjanjikan keuntungan yang menarik, tetapi tidak jarang petani cabai menemui kegagalan dan juga kerugian yang cukup besar (Wiryanta, 2006; Sunarmani, 2012). Penanganan pascapanen yang tidak menerapkan Good Handling Practices (GHP) mengakibatkan kualitas cabai menurun dan daya simpan yang sangat singkat (Sembiring, 2009; Acedo, 2012), sehingga cabai rawit seringkali dijumpai sudah membusuk sebelum sampai di tangan konsumen. Jumlah kerusakan dan pembusukan yang terjadi mulai dari lapangan sampai ke tingkat pengecer dapat mencapai 23\% (Suyanti, 2009; FAO, 2014). Pembusukan cabai ini salah satunya disebabkan oleh kehadiran atau serangan bakteri (Hadas, et. al., 2001). Penelitian tentang bakteri pembusuk pada cabai ini masih terbatas, khususnya di Indonesia sebagai negara tropis. Sebagian besar pustaka yang ditulis merujuk pada penelitian tentang penyebab cabai busuk yang dilakukan di daerah sub tropis (Black et al., 1991; Berke et al., 2005), sehingga terdapat kemungkinan ditemukannya bakteri penye- bab busuk buah cabai yang berbeda antara negara tropis dan sub tropis. Berdasarkan permasalahan tersebut, penelitian ini bertujuan untuk mengisolasi dan menguji sifat biokimia bakteri pembusuk dalam buah cabai rawit.

\section{METODE PELAKSANAAN}

\section{Bahan}

Bahan yang dipergunakan dalam penelitian ini adalah buah cabai rawit yang membusuk yang dibeli dari supermarket di Salatiga, Nutrient Agar (Merck), larutan kristal violet (Sigma-Aldrich), larutan oksalat (Sigma-Aldrich), larutan iodium 5\% (Sigma-Aldrich), larutan safranin (SigmaAldrich), larutan glutamin (Merk), pepton (Merck), tryptone (Merck), bacterial agar (Oxoid), yeast extract (Merck), kalsium karbonat (Sigma-Aldrich), dektrose (Merck), starch agar (Sigma-Aldrich), phenol red broth glucose (Merck), glukosa (Merck), laktosa (Merck), sodium cloride (Merck), $\mathrm{KOH} 40 \%, \mathrm{Ca}_{3}\left(\mathrm{PO}_{4}\right),(\mathrm{NH} 4)_{2} \mathrm{SO}_{4}, \mathrm{NaCl}$, $\mathrm{MgSO}_{4} .7 \mathrm{H}_{2} \mathrm{O}, \mathrm{KCl}, \mathrm{MnSO}_{4}, \mathrm{FeSO}_{4}$, kuning telur, kovac's reagent (Sigma-Aldrich), methyl red (Sigma-Aldrich), $\alpha$-naftol (Sigma-Aldrich), etanol (Merck), dan aseton (Merck).

\section{Alat}

Alat yang diperlukan meliputi: cawan petri, tabung reaksi, laminar air flow cabinet, inkubator (Memmert), jarum ose needle, micro pippet, mikroskop cahaya (Olympus CX-23).

\section{Tahapan penelitian}

Tahapan penelitian yang dilakukan untuk isolasi, purifikasi, hingga karakterisasi biokimia bakteri pembusuk buah cabai rawit (diadaptasi dari Kashyap, Chandra, dan Tewari, 2000; Hadas, et. al., 2001) adalah sebagai berikut: 


\section{Isolasi bakteri}

Media NA disiapkan untuk proses isolasi Setelah media tersebut sudah siap digunakan, cabai rawit yang membusuk (terlihat layu, kulit buah lembek, berair, dan berbau) dispray dengan etanol pada bagian permukaan kulit buah, lalu bagian dalam dicuplik dengan jarum ose dan digoreskan pada permukaan media NA dengan metode kuadran. Kemudian, sampel diinkubasi selama 24-48 jam pada suhu $37{ }^{0} \mathrm{C}$.

\section{Purifikasi bakteri}

Purifikasi dilakukan pada saat media yang sudah ditumbuhi bakteri dalam proses isolasi. Kemudian, koloni bakteri tersebut dicuplik dan digoreskan ulang pada media NA yang baru hingga memperoleh isolat yang seragam/terpisah. Untuk memastikan kemurnian isolat, proses ini dilakukan sebanyak 3 kali dan diamati morfologi selnya.

\section{Karakteristik biokimia bakteri}

Karakteristik biokimia bakteri pembusuk pada cabai rawit dilakukan dengan uji katalase, fosfatase, lechitinase, Yellow Pigmen pada YDC (Yeast Dextrose Calciumcarbonate), pektinase, hidrolisis pati, fermentasi laktosa, indol, methyl red, vogesproskauer (Wolfe and Amsterdam, 1968; McDevitt, 2009; EPPO, 2013;).

Tahapan penelitian tersebut dapat dideskripsikan melalui diagram alir berikut dibawah ini:

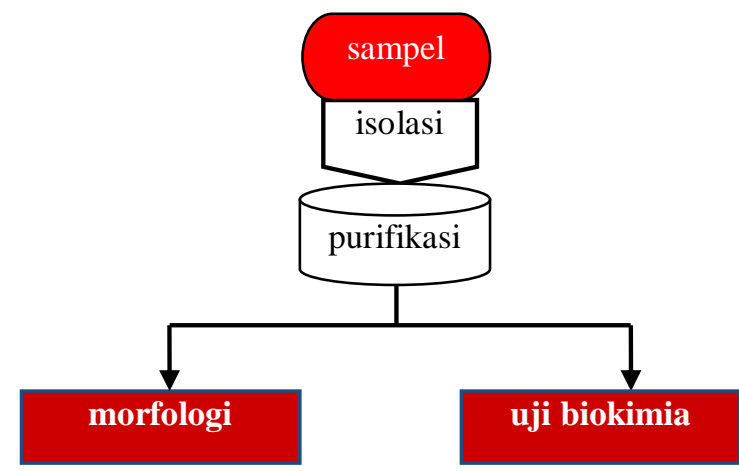

Gambar 1. Diagram alir penelitian

Data diperoleh melalui pengamatan morfologi sel dan koloninya serta hasil uji biokimia, kemudian dianalisis dan diintrepretasi secara diskriptif.

\section{HASIL DAN PEMBAHASAN}

\section{Isolasi dan purifikasi}

Isolasi dan purifikasi merupakan tahapan yang penting untuk memisahkan atau memindahkan mikroba yang tercampur dari lingkungannya, sehingga diperoleh kultur murni atau biakan murni, seperti koloni bakteri yang isolasi dari cabai rawit yang membusuk (Gambar 1.).

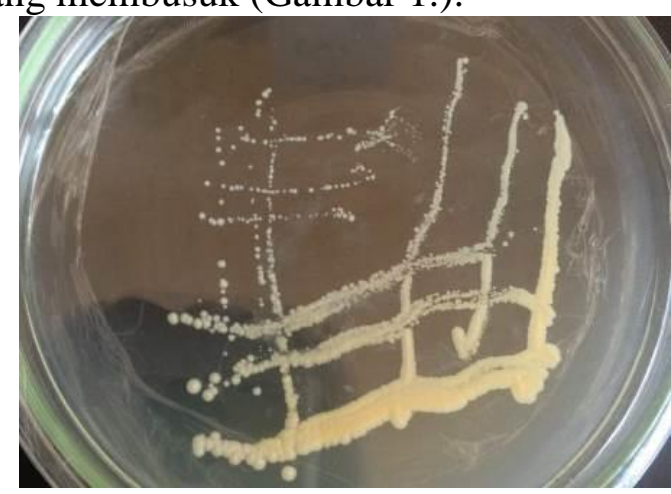

Gambar 2. Morfologi Koloni Bakteri Pembusuk Buah Cabai Rawit

Gambar 1. menunjukkan bahwa koloni bakteri yang membusukkan buah cabai rawit membentuk tepian koloni yang bergerigi dengan permukaan koloni terlihat halus dan mengkilap. Koloni tersebut berwarna kuning setelah diinkubasi 48 jam, sedangkan pengamatan gram menunjukkan bahwa sel bakteri pembusuk buah cabai rawit berbentuk batang atau basil (Gambar 2).

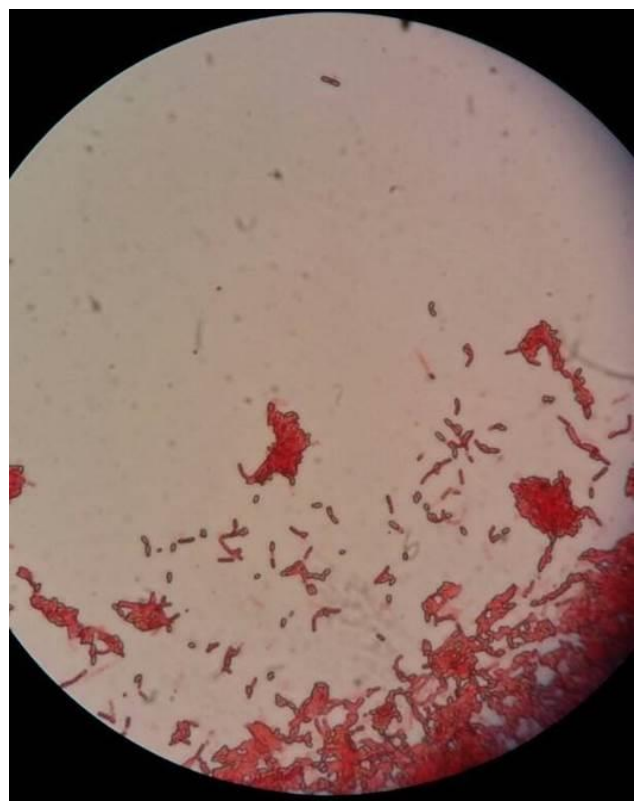

Gambar 3. Pengecatan gram sel bakteri pembusuk buah cabai rawit 
Gingichashvili et al. (2020) melaporkan bahwa Bacillus mempunyai kemampuan adaptasi dalam berbagai media dan kondisi lingkungan, sehingga morfologi koloni Bacillus dapat mengekspresikan warna maupun bentuk koloni yang berbeda pada saat ditumbuhkan pada berbagai media. Lebih lanjut, Claus dan Barkeley (1986) dan Lu, Guo, dan Liu (2018) menyatakan bahwa genus Bacillus mempunyai sifat fisiologibiokimia yang menarik karena masingmasing spesiesnya mempunyai kemampuan yang berbeda-beda, diantaranya: (1) mampu mendegradasi senyawa organik, seperti: protein, pati, selulosa, hidrokarbon; (2) mampu mengikat nitrogen yang berperan dalam nitrifikasi dan denitrifikasi; (3) mampu menghasilkan antibiotik; (5) serta memiliki sifat khemolitotrof, aerob atau fakultatif anaerob, asidofilik, psikrofilik, atau termofilik. Untuk itu, maka uji biokimia bakteri pembusuk buah cabai rawit ini perlu dilakukan agar dapat memahami karakteristik yang khas.

\section{Karakteristik biokimia}

Pengujian biokimia didasarkan pada ekspresi hasil metabolisme yang diakibatkan oleh aktivitas enzim yang dimiliki oleh suatu spesies bakteri. Setiap hasil uji biokimia dibandingkan dengan bakteri Xanthomonas campetris ataupun Erwinia carotovora seperti yang pernah dilakukan oleh Black, et al (1991). Tabel 1. merupakan hasil pengujian metabolisme yang memperlihatkan sifat-sifat atau karakteristik biokimia bakteri pembusuk dalam buah cabai rawit.

Tabel 1. Karakteristik Biokimia Bakteri Pembusuk dalam Cabai Rawit

\begin{tabular}{lll}
\hline No & Jenis Uji Biokimia & Hasil Uji \\
\hline 1 & Katalase & positif \\
2 & Fosfatase & positif \\
3 & Lechitinase & positif \\
4 & Yeast Dextrose Calcium & positif \\
& Carbonate (YDC) & \\
5 & Pektinase & negatif \\
6 & Hidrolisis pati & negatif \\
7 & Fermentasi laktosa & negatif \\
8 & Indol & negatif \\
9 & Methyl red & positif \\
10 & Voges-Proskeur & negatif \\
\hline
\end{tabular}

Kemampuan bakteri dalam menghasilkan enzim katalase ditunjukkan kemampuannya dalam memecahkan $\mathrm{H}_{2} \mathrm{O}_{2}$ (hidrogen perioksida) menjadi $\mathrm{H}_{2} \mathrm{O}$ (air) dan $\mathrm{O}_{2}$ (oksigen). Hasil positif dengan indikator adanya gelembung disekitar koloni saat ditetesi $\mathrm{H}_{2} \mathrm{O}_{2}$. Adanya gelembung udara menunjukkan proses pemecahan $\mathrm{H}_{2} \mathrm{O}_{2}$ oleh enzim katalase yang dihasilkan oleh bakteri itu sendiri untuk membentuk sistem pertahanan dari toksik $\mathrm{H}_{2} \mathrm{O}_{2}$ yang dihasilkannya (Lay, 1994; Reiner, 2010).

Uji fosfat positif yang ditandai zona bening media pikovskaya agar di sekitar koloni mengindikasikan adanya aktivitas enzim fosfatase yang dilakukan oleh jenis bakteri pelarut fosfat. Pada umumnya, efek pelarutan fosfat disebabkan oleh adanya produksi asam organik, seperti: asam asetat, asam format, asam laktat, asam oksalat, asam malat, dan asam sitrat yang dihasilkan oleh metabolisme bakteri (Khan et al., 2009). Media pikovskaya agar mempunyai warna putih keruh disebabkan kandungan trikalsium fosfat $\mathrm{Ca}_{3}\left(\mathrm{PO}_{4}\right)_{2}$ sebagai fosfat tidak larut dalam medium. Zona bening pada agar yang terbentuk di sekitar koloni akibat pelarutan suspensi trikalsium fosfat $\mathrm{Ca}_{3}\left(\mathrm{PO}_{4}\right)_{2}$.

Kelompok bakteri yang mempunyai enzim lechitinase ditunjukkan dengan kemampuannya dalam memecahkan lesitin (trigliserida) menjadi digliserida (Esselman and Liu, 1961). Uji positif lechitinase menghasilkan zona buram yang menyebar di tepi koloni saat bakteri diinokulasikan ke dalam media YPA yang ditambahkan dengan kuning telur dan $\mathrm{NaCl} 0,9 \%$. Hasil positif ini mengkonfirmasi bahwa bakteri pembusuk pada buah cabai rawit ini dapat memproduksi enzim lechitinase. Sedangkan, pengujian yellow pigment bertujuan untuk mengetahui kemampuan bakteri memproduksi pigmen karotenoid (Akbar et al., 2015), yang ditunjukkan dengan koloni bakteri yang berwarna kuning pada medium YDC setelah diinkubasi pada suhu $37{ }^{\circ} \mathrm{C}$ selama 48 jam.

Pektinase merupakan enzim yang spesifik menghidrolisis pektin melalui reaksi depolimerisasi (hydrolase dan lyase) dan de- 
esterifikasi (esterase). Dalam lingkungan alaminya, pektinase diproduksi oleh bakteri, khamir, maupun kapang (Kapoor et al., 2000; Kashyap, Chandra, dan Tewari, 2000, 2000). Hasil uji pektinase negatif pada media CVP (Crystal Violet Pectate) menunjukkan bahwa bakteri pembusuk buah cabai rawit tidak memproduksi enzim pektinase, sehingga tidak menunjukkan zona bening di sekitar pertumbuhan koloni.

Hasil negatif di sekeliling medium agar pati yang tidak tampak zona bening juga mengindikasikan bahwa bakteri tersebut tidak memiliki enzim amilase untuk menghidrolisis pati maupun memanfaatkan pati sebagai sumber energi dan karbon. Jika suatu spesies mampu menghidrolisis pati, maka hasil penguraian senyawa tersebut dapat menghasilkan maltosa, yang kemudian maltosa ini dihidrolisis lebih lanjut menjadi glukosa (Purba, 2009). Penelitian yang terkait dengan kemampuan Bacillus dalam mendegradasi pati dilakukan oleh Saputra, Triwidodo, dan Arif (2015), yang hasil menunjukkan bahwa Bacillus spp. pada buah tomat mampu menghidrolisis pati dengan sangat baik.

Pengujian fermentasi laktosa, indol, methyl red, voges-proskauer dilakukan untuk mengetahui sifat-sifat bakteri yang lebih spesifik, khususnya golongan Enterobacteriaceae (Wolfe dan Amsterdam, 1968; McDevitt, 2009). Hasil negatif pada uji fermentasi laktosa ditunjukkan dengan media kultur yang berubah warna menjadi merah muda, sehingga bakteri pembusuk buah cabai rawit tidak dapat memanfaatkan laktosa sebagai sumber karbon dan memfermentasikannya menjadi asam laktat. Sedangkan uji indol menunjukkan kapasitas dan kemampuan bakteri dalam memecahkan senyawa indol dari asam amino triptofan, yang hasil positifnya ditandai dengan terbentuknya cincin merah terang di atas permukaan medium dalam tabung setelah penambahan kovac's reagent. Namun demikian, bakteri pembusuk buah cabai rawit menunjukkan hasil negatif dalam pengujian indol.
Produksi asam selama pemecahan gula (glukosa) dalam proses fermentasi dapat dideteksi dengan uji methyl red. Hasil uji yang positif ditunjukkan setelah penambahan indikator methyl red dalam media kalduglukosa dengan bufer pepton dan fosfat dipotassium berubah menjadi merah pada permukaan koloni seperti ditunjukkan pada Tabel 1. Fermentasi glukosa ini dapat menghasilkan sejumlah besar asam laktat, asam asetat, asam suksinat, asam format, etanol, karbondioksida, dan hidrogen. Sedangkan uji voges-proskauer digunakan untuk mengidentifikasi bakteri yang mampu memfermentasikan karbohidrat menjadi 2,3butanadiol sebagai produk utama. Penambahan KOH $40 \%$ dan larutan $\alpha$-naphtol $5 \%$ dalam etanol dapat mengindikasikan adanya asetolin (asetilmethylcarbinol). Asetolin merupakan senyawa utama dalam pembentukan 2,3butanadiol (McDevitt, 2009). Hasil yang negatif ditunjukkan setelah penambahan $\mathrm{KOH}$ tidak terjadi perubahan warna menjadi merah muda dalam media yang telah dikultivasi bakteri pembusuk cabai rawit.

Berdasarkan pengamatan morfologi dan berbagai uji biokimia tersebut diatas dapat diatas, bakteri pembusuk pada cabai rawit memiliki kemampuan melarutkan fosfat yang identik dengan golongan rhizobakteri, diantraanya Bacillus spp. dan Pseudomonas spp. Khan et al., (2009) menyatakan bahwa bakteri Bacillus spp. dan Pseudomonas spp. merupakan golongan bakteri yang dapat memperbaiki ketersediaan fosfat di dalam tanah secara efektif. Pengujian pektinase negatif mengkonfirmasi bahwa bakteri ini tidak sama dengan Erwinia carotovora. Hadas (2001) melaporkan bahwa bakteri E. carotovora dalam pengujian pektinase terdapat hasil yang positif. Sedangkan pengujian hidrolisis pati dengan hasil negatif pada sampel menunjukkan bahwa bakteri pembusuk buah cabai rawit berbeda dengan pada bakteri Xanthomonas campestris $p v$. campetris yang mampu menghidrolisis pati (Radunovic, 2012). Dengan demikian, bakteri tersebut diduga tidak dekat dengan bakteri Xanthomonas sp. 
Selanjutnya, melalui pengujian uji fermentasi laktosa, indol, methyl red dan vogesproskaeur menunjukkan bahwa bakteri yang diujikan mengalami perbedaan karakteristik dari uji-uji biokimia sebelumnya.

Berdasarkan Bergey's Manual of Systematic Bacteriology (Krieg et al., 2010), uji laktosa dan uji indol yang dengan hasil negatif menunjukkan sifat bakteri pembusuk pada buah cabai rawit tersebut dekat dengan bakteri Yersinia pestis dan $Y$. pseudotuberculosis, Shigella sonnei, Serratia marcescens dan S. liquefaciens, Proteus penneri dan P. mirabilis, Erwinia cacticida, serta Salmonella bongori dan S. enterica. Sedangkan hasil positif pada uji methyl red dan negatif pada uji voges-proskauer dapat mengindikasikan bahwa Citrobacter freundii, Serratia fonticola, Klebsiella pneumoniae. Sehingga, ke-empat uji ini mengkonfirmasi bahwa bakteri pembusuk pada buah cabai tidak sama dengan karakteristik Erwinia carotovora seperti yang dilaporkan oleh Black et al., (1991).

\section{KESIMPULAN}

Berdasarakan hasil penelitian disimpulkan bahwa bakteri pembusuk dalam buah cabai rawit, selnya berbentuk batang dan koloninya bergerigi dengan permukaan koloni terlihat halus dan mengkilap. Karakteristik biokimia melalui uji katalase, fosfatase, lechitinase, yellow pigment, pektinase, hidrolisis pati menunjukkan bahwa bakteri tersebut mempunyai aktivitas enzim katalase, aktivitas enzim fosfatase, mampu memproduksi lechitinase. mampu memproduksi karotenoid, namun bakteri tersebut tidak dapat menghidrolisis pati dan pektin. Karakteristik tersebut menunjukkan ciri-cirinya yang tidak mendekati bakteri Xanthomonas campestris. Sedangkan uji fermentasi laktosa, indol, methyl red, dan voges-proskaeur menunjukkan bahwa bakteri pembusuk buah cabai rawit tidak sama karakteristiknya dengan spesies bakteri Erwinia carotovora. Berdasarkan observasi moroflogi dan uji biokimia ini ini, maka untuk memastikan spesies bakteri pembusuk pada cabai rawit tersebut perlu dilakukan identifikasi molekuler melalui metode $16 \mathrm{~S}$ rRNA pada penelitian selanjutnya.

\section{UCAPAN TERIMA KASIH}

Kami mengucapkan terima kasih kepada Universitas Kristen Satya Wacana yang telah memfasilitasi penelitian ini melalui Hibah Penelitian Internal Wajib.

\section{DAFTAR PUSTAKA}

Acedo, A. L. (2012). Postharvest technology for fresh chili pepper in Cambodia, Laos, and Vietnam. Tainan: Asian Vegetables Research and Development Center.

Akbar, A., Ahmad, M., Azra, Neelam, Khan, S. Z., \& Ahmad, Z. (2015). Characterization of the causal organism of soft rot of tomatoes and other vegetables and evaluation of its most aggressive isolates. American Journal of Plant Sciences, 6, 511517.

Badan Pusat Statistik. (2015). Distribusi perdagangan komoditas cabai merah Indonesia 2015. Jakarta: Badan Pusat Statistik.

Berke, T., Black, L. L., Talekar, N. S., Wang, J. F., Gniffke, P., Green, S. K., Wang, T. C., \& Morris, R. (2005). Suggested cultural practices for chili pepper. In: CENTER, A. V. R. A. D. (ed.). Shanhua: Asian Vegetables Research and Development CenterThe World Vegetable Center.

Black, L. L., Green, S. K., Hartman, G. L., \& Poulos, J. M. (1991). Peppers diseases: a field guide. Taipei: Asian Vegetables Research and Development Centre.

Czajkowski, R, Perombelon, M. C. M., Jafra, S., Lojkowska, E., Potrykus, M., van der Wolf J. M., \& Sledz, W. (2015). Detection, identification and differentiation of Pectobacterium and Dickeya species causing potato 
blackleg and tuber soft rot. Ann. Appl. Biol., 166 (1), 18-38.

Claus, D., \& Berkeley, R. C. W. (1986). Genus Bacillus, Bergey's manual of sistematic bacteriology. Baltimore: Lippincott Willians dan Wilkins.

Dermawan, R., \& Harpenas, A. (2010). Budidaya cabai unggul, cabai besar, cabai keriting, cabai rawit, dan paprika. Jakarta: Penebar Swadaya.

EPPO. (2013). Xanthomonasspp. (Xanthomonas euvesicatoria, Xanthomonas gardneri, Xanthomonas perforans, Xanthomonas vesicatoria) causing bacterial spot of tomato and sweet pepper. Paris: European Plant Protection Organization

Esselman, M. T., \& Liu, P. V. (1961). Lecithinase production by gramnegative bacteria. J. Bacteriol., 81 (6), 939-945.

FAO. (2014). Budidaya cabai yang baik dan benar. Jakarta: Food and Agriculture Organization dan Kementerian Pertanian Republik Indonesia.

Gingichashvili, S., Duanis-Assaf, D., Shemesh., M., Featherstone, J. D. B., Feuerstein, O., \& Steinberg, D. (2020). The adaptive morphology of Bacillus subtilis biofilms: a defense mechanism against bacterial starvation. Microorganisms, 28 (62),doi:10.3390/microorganisms8010 062

Hadas, R., Kritzman, G., Gefen, T., \& Manulis, S. (2001). Detection, quantification and characterization of Erwinia carotovora ssp. carotovora contaminating pepper seeds. Plant Pathology, 50 (1), 117-123.

Kapoor, M. Q. K., Bhusan, B. B., Dadhich, K. S., \& Hundal, G. S. (2000). Production and partial purification and characterization of a thermo-alkali stable polygalacturonase from Bacillus sp. MG-CP-2. Process. Biochem., 36 (1), 467-473.

Kashyap, D. R., Chandra, S. K. A., \& Tewari, R. (2000). Production, purification and characterization of pectinase from a Bacillus sp. DT7. World J. Microbiol. Biotechnol., 16 (1), 277-282.

Khan A.A, Jilani G, Akhtar M.S, Naqvi S.M.S, \& Rasheed M. (2009). Phosphorus so-lubilizing bacteria: occurrence, mechanisms and their role in crop production. J. Agric. Biol. Sci., 1 (1), 48-58.

Krieg, N. R., Ludwig, W., Whitman, W. B., Hedlund, B. P., Paster, B. J., Staley, J. T., Ward, N. \& Brown, D. (2010). Bergey's manual of systematic bacteriology, 2nd ed., vol. 4, New York: Springer-Verlag.

Lay, B. W. (1994). Analisis mikroba di laboratorium. Jakarta: PT Raja Grafindo Persada.

Lu, Z., Guo, W., \& Liu, C. (2018). Isolation, identification and characterization of novel Bacillus subtilis. Vet. Med. Sci., 80(3): 427-433. doi: 10.1292/jvms.160572

McDevitt, S. (2009). Methylred and vogesproskauer test protocol. New York: American Society for Microbiology.

Purba, E. (2009). Hidrolisis pati ubi kayu (Manihot Esculenta) dan pati ubi jalar (Impomonea batatas) menjadi glukosa secara cold process dengan acid fungal amilase dan glukoamilase. Skripsi. Lampung: Universitas Lampung,

Prajnanta, F. (2007). Agribisnis cabai hibrida. Jakarta: Penebar Swadaya.

Radunovic, D., \& Balaz, J. (2012). Occurrence of Xanthomonas campestris pv. campestris (Pammel, 1895) Dowson 1939, on Brassicas in Montenegro. Pestic. Phytomed., 27 (2), 131-140.

Reiner, K. (2010). Catalase test protocol. New York: American Society for Microbiology.

Saputra, R., Triwidodo, A., \& Arif, W. (2015). Uji aktivitas antagonistik beberapa isolat Bacillus spp. terhadap penyakit layu bakteri (Ralstonia solanacearum) pada beberapa varietas 
tomat dan identifikasinya. Biodev. Wiryanta. (2006). Bertanam cabai pada Indo., 1 (5), 1116-1122. musim hujan. Tangerang: Agromedia.

Sembiring, N.N. (2009). Pengaruh jenis bahan pengemas terhadap kualitas produk cabai merah (Capsicum annum L). Tesis. Medan: Universitas Sumatera Utara.

Sunarmani. (2012). Teknologi penanganan pascapanen cabai. Makalah Pelatihan Spesialisasi Widyaiswara. Bogor: BBPP Pascapanen Pertanian.

Suyanti. (2009). Membuat aneka olahan cabai. Jakarta: Penebar Swadaya.

Wolfe, M. W. \& Amsterdam D. (1968). New diagnostic system for the identification of lactose-fermentating gram-negative rods. Applied Microbiol, 16 (10), 1528-1531. 